\title{
Effectiveness of lateral and secondary canal filling with different endodontic sealers and obturation techniques
}

\author{
Efetividade de preenchimento de canais laterais e acessórios com \\ diferentes cimentos endodônticos e técnicas de obturação
}

\author{
Camila Krusser Teixeira* \\ Sabrina Sasso Da Silva** \\ Silvana Beltrami Gonçalves Waltrick ${ }^{* * *}$ \\ Renata Dornelles Morgental ${ }^{* * * *}$ \\ Fabiana Vieira Vier-Pelisser ${ }^{* * * *}$ \\ Roberta Kochenborger Scarparo ${ }^{* * * * *}$
}

\begin{abstract}
Objective: this study aimed to compare the performance of the new endodontic sealer GuttaFlow 2 (GF2) with two conventional sealers - AH Plus (AHP) and EndoFill (EF) - for filling artificial lateral and secondary canals with the following two obturation techniques: cold lateral condensation (CLC) and Tagger's hybrid technique (THT). Materials and method: sixty single-rooted human teeth were selected and subjected to root canal preparation. Next, specimens were subjected to a diaphanization method. During this process, artificial lateral and secondary canals were produced at 2, 5, 9, and $12 \mathrm{~mm}$ from the root apex. The specimens were randomly assigned into six groups $(n=10)$ according to endodontic sealer (GF2, AHP, or EF) and obturation technique (CLC or THT). The filling of lateral and secondary canals was analyzed by stereomicroscopy. The images were obtained and transferred to the Imagel software. The mean filling percentages were calculated considering total linear measurements of artificial canals and their filled portions. Data were compared by two-way Anova, followed by Bonferroni Post-Hoc Test, at 5\% significance level. Results: all materials showed the ability to penetrate into artificial lateral and secondary canals. There was no significant difference $(P>0.05)$ between sealers and obturation techniques. Only GF2 showed a significantly improved flow into lateral canals when compared to secondary canals $(P<0.05)$. Conclusion: GF2 shows proper flow for filling ramifications of the main
\end{abstract}

root canal, but presents no advantage over conventional zinc oxide-eugenol-based or epoxy resin-based filling materials.

Keywords: Endodontics. Root canal filling materials. Root canal filling.

\section{Introduction}

Root canal filling is the final operative phase of endodontic treatment. It completes the clinical procedures of cleaning and shaping, and it should allow a hermetic seal of the root canal system ${ }^{1}$. However, filling ramifications of the main root canal might represent a challenge $e^{1,2}$. When lateral canals, isthmuses, and apical deltas are not filled, they may hold an infection even if the main root canal is completely filled ${ }^{3}$. De Deus ${ }^{4}$ investigated the frequency, location, and direction of lateral, secondary, and accessory canals. The author observed the highest incidence at the apical root third, followed by middle and coronal segments. These ramifications are clinically significant because they provide communication between pulp and periodontal tissues; thus, they are closely related to endo-periodontal disease ${ }^{5}$.

DDS, Departamento Clínico, Endodontia, Faculdade de Odontologia, Pontifícia Universidade Católica do Rio Grande do Sul, Porto Alegre, RS, Brasil. DDS, Departamento Clínico, Endodontia, Faculdade de Odontologia, Pontifícia Universidade Católica do Rio Grande do Sul, Porto Alegre, RS, Brasil. Ph.D., Departamento Clínico, Endodontia, Faculdade de Odontologia, Pontifícia Universidade Católica do Rio Grande do Sul, Porto Alegre, RS, Brasil. Ph.D., Departamento de Estomatologia, Endodontia, Faculdade de Odontologia, Universidade Federal de Santa Maria, Santa Maria, RS, Brasil. Ph.D., Departamento Clínico, Endodontia, Faculdade de Odontologia, Pontifícia Universidade Católica do Rio Grande do Sul, Porto Alegre, RS, Brasil. Ph.D., Departamento de Odontologia Conservadora, Endodontia, Faculdade de Odontologia, Universidade Federal do Rio Grande do Sul, Porto Alegre, RS, Brasil. 
In this context, it is important to use a filling material with good sealing and flow properties, as well as radiopacity, dimensional stability, and low cytotoxicity ${ }^{6}$. Up to this moment, there is no product combining all the ideal properties, which may explain the need for continuous development of new endodontic sealers. Currently, there are commercially available sealers composed of zinc oxide-eugenol, glass ionomer, resin, silicone, calcium hydroxide, and MTA ${ }^{6,7}$.

One of the innovative materials released on the market is the GuttaFlow (Coltène Whaledent, Altstatten, Switzerland), which is based on silicone and gutta-percha powder. It is a non-eugenol radiopaque material, claimed to slightly expand during setting ${ }^{7}$ and to provide suitable sealing ability ${ }^{8}$. More recently, this product has been modified giving rise to GuttaFlow 2 (Coltène Whaledent, Altstatten, Switzerland). According to the manufacturer, this new endodontic sealer presents good physicochemical and antimicrobial properties ${ }^{9}$. However, it has been poorly investigated ${ }^{10-12}$ and it should be further compared with existing materials. The AH Plus (DeTrey Dentsply GmbH, Konstanz, Germany) is based on epoxy resin and it is considered a goldstandard material for root filling due to its long history of clinical success ${ }^{6}$ and remarkable bond strength to dentin ${ }^{13}$. EndoFill (Dentsply, Petrópolis, $\mathrm{RJ}$, Brazil) is another conventional sealer, which is composed of zinc oxide-eugenol and offers a long time of use and good clinical performance ${ }^{6,14}$.

The flow property of a sealer is related to its ability to penetrate into irregularities or ramifications of the main root canal and dentinal tubules ${ }^{15}$. This shows the importance of evaluating such property in the aforementioned sealers.

Another factor that influences the performance of endodontic sealers is the technique used for root filling. Cold lateral condensation is still the most used technique worldwide, in which finger spreaders are used lateral to the main gutta-percha point surrounded by sealer, thus creating space for accessory gutta-percha points ${ }^{16}$. Tagger's hybrid technique is a modification of McSpadden's technique and combines thermomechanical compaction with lateral condensation in the apical root third. Its advantages include reduced filling time and operator fatigue, as well as allowing better filling of canal irregularities, with both sealer and gutta-percha ${ }^{17}$.

Considering the above, this study aims to compare the flow capacity of three root canal sealers (EndoFill, AH Plus, and GuttaFlow 2), evaluating the filling of artificial lateral and secondary root canals with two obturation techniques (cold lateral condensation and Tagger's hybrid technique).

\section{Materials and method}

The Ethics Committee of the Pontifical Catholic University of Rio Grande do Sul (PUCRS), Porto Alegre, Brazil (Protocol n. 0041/13) approved this research.

\section{Specimen preparation}

Sixty single-rooted human teeth were selected for this study. Teeth presented straight or slightly curved roots, absence of root resorption or fracture, closed apex, and single root canal. Teeth were decoronated with carborundum discs, and root length was standardized at $15 \mathrm{~mm}$. Specimens were prepared by a single operator. First, the middle/cervical third was prepared with \#1 and \#2 Gates-Glidden burs (Dentsply-Maillefer, Ballaigues, Switzerland). Root canals were manually instrumented $1 \mathrm{~mm}$ short of the apex up to a \#40 K-file (Dentsply-Maillefer, Ballaigues, Switzerland). Next, they were instrumented up to a \#60 K-file following a step-back technique. Irrigation was performed with $2.5 \%$ sodium hypochlorite $(\mathrm{NaOCl})$ solution (Asfer, São Caetano do Sul, SP, Brazil) throughout the preparation procedure. A final flush with $17 \%$ EDTA solution was applied. The chelating agent remained in the root canal for 3 minutes and then it was renewed and agitated with a hand K-file at every minute. Lastly, $2.5 \% \mathrm{NaOCl}$ was used again and root canals were dried with sterile absorbent paper points (Dentsply, Petrópolis, RJ, Brazil).

\section{Preparation of lateral and secondary canals with the tooth-clearing technique}

The preparation of artificial lateral and secondary canals was performed during the toothclearing method, as previously described ${ }^{18,19,20}$. The specimens were briefly immersed in 5\% nitric acid solution until reaching a rubber-like consistency (approximately 4 days with daily renewal). Then, \#10 K-files were inserted into the root surface until they reached the main root canal. These artificial canals were placed on the buccal root surface at 2 and $9 \mathrm{~mm}$ from the apex, and on the lingual root surface at 5 and $12 \mathrm{~mm}$ from the apex, creating two lateral canals and two secondary canals according to the classification of Pucci and Reig'2.

Teeth were washed in running water for 4 hours and dehydrated with increasingly concentrated solutions of alcohol $(80 \%, 90 \%$, and 99\% ethanol). Finally, specimens were immersed in methyl salicylate in order to restore their initial consistency.

\section{Distribution of specimens and root canal obturation}

Teeth were randomly divided into six experimental groups $(n=10)$ according to the root canal filling material and technique used, as follows: EndoFill + cold lateral condensation (CLC); AH Plus + CLC; GuttaFlow $2+$ CLC; EndoFill + Tagger's hybrid technique (THT); AH Plus + THT; GuttaFlow $2+$ THT. 
In CLC groups, the gutta-percha master point was selected according to the last instrument used at the working length $(14 \mathrm{~mm})$. This technique involved the placement of a well-fitted gutta-percha master cone covered by the respective endodontic sealer, followed by the introduction of a number of auxiliary gutta-percha points aided by a finger spreader. Next, excess gutta-percha was cut off at the cementoenamel junction (CEJ) level.

In THT groups, the CLC technique was performed for sealing the apical third, followed by the use of a \#50 McSpadden compactor for sealing middle and cervical thirds.

Then, teeth were stored in a humid environment for 60 hours to allow sealers to set completely. The roots were dehydrated one more time in ascending concentrations of alcohol and immersed in methyl salicylate to achieve optimal transparency.

\section{Stereomicroscopy}

Samples were analyzed under a stereomicroscope (Zeiss, Jena, Germany) and the filling of artificial lateral and secondary canals was evaluated. The specimens were photographed with a digital camera attached to the stereomicroscope at $\times 7$ magnification (Figure 1) and the images were transferred to the Image J software (NIH $1.49 \mathrm{~m}$ version for Mac). The total linear extension of the artificial canals and their filled portions were measured. The percentage of filling in relation to the entire length of the ramification was calculated and considered for statistical analysis.

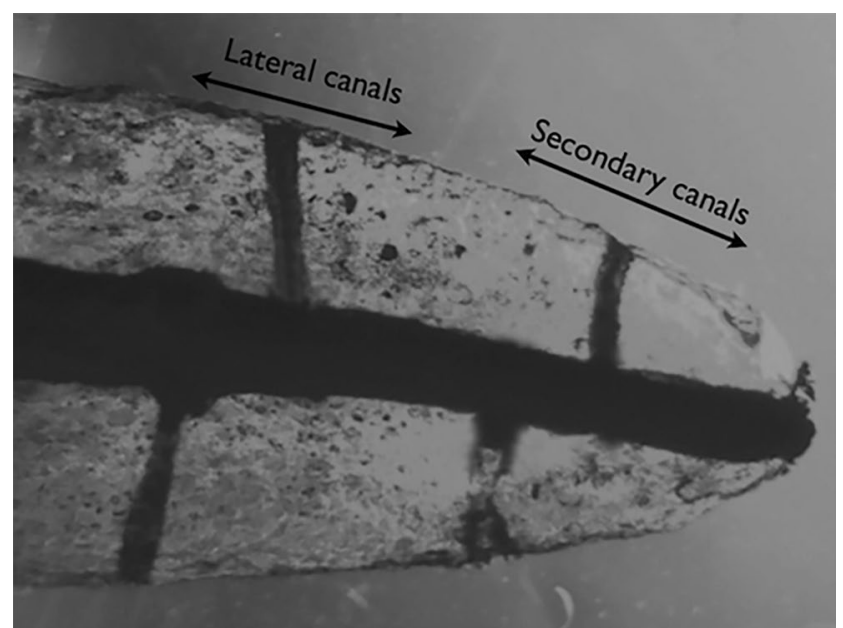

Figure 1 - Image of a decalcified and cleared tooth under stereoscopic microscope

Fonte: dos autores.

\section{Data analysis}

Data were compared by two-way ANOVA followed Bonferroni post-hoc test, using the GraphPad Prism 6 software (GraphPad Software Inc., La Jolla, CA, USA) at $5 \%$ significance.

\section{Results}

All sealers and obturation techniques allowed penetration into lateral and secondary canals, with mean filling percentage ranging from 35 to $71 \%$. There was no significant difference between sealers and obturation techniques $(\mathrm{P}>.05)$. Only GuttaFlow 2 showed significant difference $(\mathrm{P}<.05)$ in flow into lateral canals compared to secondary canals, as shown in Figure 2.

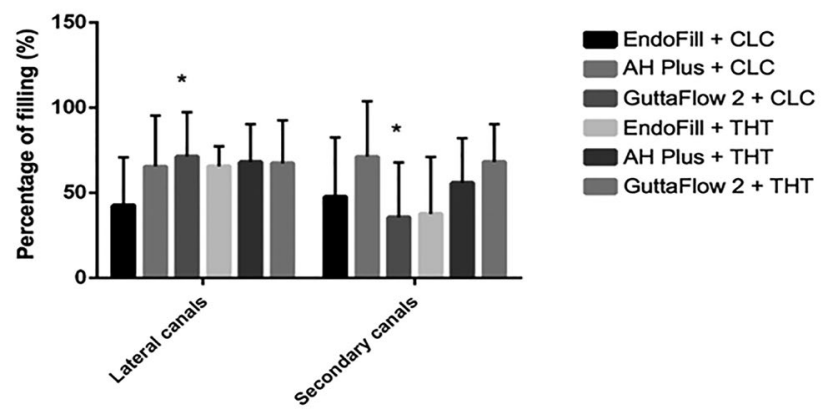

Figure 2 - Percentage of linear filling of lateral and secondary canals obtained after obturation with EndoFill, AH Plus or GuttaFlow 2 sealers, using cold lateral condensation technique (CLC) or Tagger's hybrid technique (THT).

Only the GuttaFlow 2, when used with lateral condensation, yielded significantly improved filling of lateral canals in relation to secondary canals $\left(^{*}\right)$.

Fonte: dos autores.

\section{Discussion}

This study compared the ability of three sealers (EndoFill, AH Plus, and GuttaFlow 2) and two obturation techniques (cold lateral condensation and Tagger's hybrid technique) to fill artificial lateral and secondary canals. The methodology applied to produce artificial canals was based on the protocol proposed by Venturi et $\mathrm{al}^{18}$. (2005) To regain tooth hardness on the filling phase and also to facilitate the visualization of results, the tooth-clearing technique was used as described in previous studies ${ }^{18-20}$. This method allows three-dimensional analysis by rendering the tooth transparent.

The results have not shown statistically significant differences between groups, but the EndoFill sealer tended to produce a poor flow compared to the other materials. Accordingly, a previous study ${ }^{19}$ has observed limitations on the flow of zinc oxide-eugenol-based sealers (ZOE). Likewise, there was a tendency for AH Plus to perform better, especially in secondary canals. When the GuttaFlow 2 sealer was used with cold lateral condensation, it allowed less penetration into secondary canals than lateral canals. This means that the GuttaFlow 2 had inferior results in difficult access areas and the AH Plus, in turn, showed similar flow ability in the middle and apical root thirds. According to Venturi et al. ${ }^{21}$ (2005), AH Plus is slightly thixotropic and thermoplastic, and it may be hypothesized that $\mathrm{AH}$ Plus became more fluid than 
ZOE sealers when heated and/or compacted. Fluidity enhances the ability of the filling materials to penetrate into root canal ramifications.

Another important aspect refers to the similarity of results obtained with cold lateral condensation and Tagger's hybrid technique. It is noteworthy that these findings are based on the linear extension of filling into ramifications of the main root canal, including both gutta-percha and sealer. Thus, despite the potential for more expressive penetration of gutta-percha with thermoplastic techniques ${ }^{17,22}$, this advantage could not be detected in the present statistical analysis. Similarly, Michelotto et al..$^{23}$ (2015) did not verify significant differences between thermomechanical and cold filling techniques, considering the penetration into ramifications of the apical third. However, in their study, the use of the McSpadden condenser increased the depth of penetration into ramifications of the middle third. It is important to emphasize differences in their methodology, since they used simulated root canals made in clear resin blocks with wider ramifications, that is, 0.3$\mathrm{mm}$ diameter vs. 0.1-mm diameter in our study.

Still on this subject, it may be inferred that the assessment of flow, exclusively of sealers, could be better observed with the cold lateral condensation technique. In this context, GuttaFlow 2 had more difficulty in filling ramifications located in the apical root segment, showing limitation in less accessible regions. Nonetheless, the material showed no disadvantages in comparison to the other sealers tested and therefore it may be considered suitable to fill the root canal system. Moreover, recent studies have shown that GuttaFlow 2 is slightly or non-cytotoxic ${ }^{10,11}$ and presents good sealing ability ${ }^{12}$.

To date, there are no other reported studies evaluating the flow of GuttaFlow 2 into lateral or secondary canals. Considering the original version of the product, the literature emphasizes its good penetration in dentinal tubules ${ }^{8}$, which may be seen as a characteristic of materials with good flow. However, in the aforementioned study, GuttaFlow was similar to a glass ionomer-based sealer (Ketac Endo, 3M-ESPE, St. Paul, MN, USA) and no comparison was made with the other materials used in this study.

Still in reference to the original formulation, Marciano et al. ${ }^{24}$ (2010) evaluated the apical portion of root canals filled with different obturation systems and sealers (including GuttaFlow), and showed similarity in the percentage of voids between groups. These findings agree with ours, indicating that GuttaFlow offers proper flowability, but it is not superior to other conventional materials. Additionally, Zhow et al. ${ }^{7}$ (2013) showed that the flow characteristics of GuttaFlow are within the parameter specified by the ISO 6876/2001.

It is noteworthy that flow is only one of the properties that contribute to root canal filling. In this regard, GuttaFlow presents post-setting expansion ${ }^{7}$ and chemical bond with gutta-percha and root canal walls ${ }^{8}$, which could influence the filling of root canal space $^{24}$ with high percentage of gutta-percha-filled areas when used in the single-cone technique or with additional accessory gutta-percha cones ${ }^{25}$. The single-cone technique has become increasingly popular, especially in root canals prepared with rotary or reciprocating nickel-titanium systems ${ }^{12,26}$. The penetration of GuttaFlow 2 into ramifications of the main canal with the single-cone technique was not investigated here and should be considered in future research.

\section{Conclusion}

GuttaFlow 2 was similar in filling lateral and secondary canals when compared to the other tested sealers (AH Plus and EndoFill). Both obturation techniques - cold lateral condensation and Tagger's hybrid technique - were effective in filling lateral and secondary canals. When using the latter technique, GuttaFlow 2 presented improved penetration into lateral canals when compared to secondary canals.

\section{Resumo}

Objetivo: o objetivo deste estudo foi comparar o desempenho do novo cimento endodôntico GuttaFlow 2 (GF2) com dois cimentos convencionais, AH Plus $(A H P)$ e EndoFill (EF), no preenchimento de canais laterais e secundários artificiais, utilizando duas técnicas de obturação, condensação lateral a frio (CLF) e técnica híbrida de Tagger (THT). Materiais e método: sessenta dentes humanos monorradiculares foram selecionados e submetidos ao preparo do canal radicular. A seguir, os espécimes foram submetidos ao método de diafanização. Durante este processo, canais laterais e secundários artificiais foram produzidos a 2, 5, 9 e $12 \mathrm{~mm}$ do ápice radicular. Os espécimes foram distribuídos aleatoriamente em 6 grupos $(n=10)$, de acordo com o cimento endodôntico (GF2, AHP ou EF) e a técnica de obturação (CLF ou THT). O preenchimento dos canais laterais e secundários foi analisado por estereomicroscopia. As imagens foram obtidas e transferidas para o software ImageJ. As porcentagens médias de preenchimento foram calculadas considerando as medições lineares totais dos canais artificiais e suas porções obturadas. Os dados foram comparados por Anova de duas vias, seguidos pelo Teste Post-Hoc de Bonferroni, com nível de significância de 5\%. Resultados: todos os materiais mostraram capacidade de penetrar em canais laterais e secundários artificiais. Não houve diferença significativa $(P>0,05)$ entre cimentos e técnicas de obturação. Somente o GF2 mostrou um fluxo significativamente melhor nos canais laterais, quando comparado aos canais secundários $(P<0,05)$. Conclusão: GF2 mostra fluxo adequado para preenchimento de ramificações do canal radicular principal; sem, no entanto, qualquer vantagem em comparação com os materiais obturadores convencionais à base de óxido de zinco-eugenol ou de resina epóxica.

Palavras-chave: Endodontia. Materiais obturadores do canal radicular. Obturação do canal radicular. 


\section{References}

1. Schilder H. Filling root canals in three dimensions. Dent Clin North Am 1967; Nov:723-44.

2. Pucci FM, Reig R. Conductos radiculares. Buenos Aires: Medico-Quirurgica; 1944.

3. $\mathrm{Xu} \mathrm{G}$, Zhang Z. Filling of the lateral canal. Report of two cases. Oral Surg Oral Med Oral Pathol 1984; 58(2):221-4.

4. De Deus QD. Frequency, location, and direction of the lateral, secondary, and accessory canals. J Endod 1975; 1(11):361-6.

5. Zehnder M, Gold SI, Hasselgren G. Pathologic interactions in pulpal and periodontal tissues. J Clin Periodontol 2002; 29(8):663-71.

6. Ørstavik D. Endodontic filling materials. Endod Topics 2014;31(1):53-67.

7. Zhou HM, Shen Y, Zheng W, Li L, Zheng YF, Haapasalo M. Physical properties of 5 root canal sealers. J Endod. 2013; 39(10):1281-6

8. Vujaskovic M, Teodorovic N. Analysis of sealing ability of root canal sealers using scanning electronic microscopy technique. Srp Arh Celok Lek 2010; 138(11-12):694-8.

9. GuttaFlow2. Brochure. [cited 2015 February 04]; Available from: http://www.coltene.com/download.php?file_id=1270.

10. Mandal P, Zhao J, Sah SK, Huang Y, Liu J. In vitro cytotoxicity of guttaflow 2 on human gingival fibroblasts. J Endod 2014; 40(8):1156-9.

11. Baldasso FER, Kopper PMP, Morgental RD, Steier L, Figueiredo JAP, Scarparo RK. Biological tissue response to a new formulation of a silicone based endodontic sealer. Braz Dent J 2016; 27(6): 657-63.

12. El Sayed MA, Taleb AA, Balbahaith MS. Sealing ability of three single-cone obturation systems: an in-vitro glucose leakage study. J Conserv Dent 2013; 16(6):489-93.

13. Collares FM, Portella FF, Rodrigues SB, Celeste RK, Leitune VC, Samuel SM. The influence of methodological variables on the push-out resistance to dislodgement of root filling materials: a meta-regression analysis. Int Endod $\mathrm{J}$ 2015; 49(9):836-49.

14. Huumonen S, Lenander-Lumikari M, Sigurdsson A, Ørstavik $\mathrm{D}$. Healing of apical periodontitis after endodontic treatment: a comparison between a silicone-based and a zinc oxide-eugenol-based sealer. Int Endod J 2003; 36(4):296-301.

15. Johnson WT, Gutmann JL. Obturation of cleaned and shaped root canal system. In: Cohen S, Hargreaves K, editors. Pathways of the pulp. 9th ed. Philadelphia: Elsevier; 2007.

16. Whitworth J. Methods of filling root canals: principles and practices. Endod Topics 2005; 12(1):2-24.

17. Tagger M. Use of thermo-mechanical compactors as an adjunct to lateral condensation. Quintessence Int Dent Dig 1984; 15(1):27-30

18. Venturi M, Di Lenarda R, Prati C, Breschi L. An in vitro model to investigate filling of lateral canals. J Endod 2005; 31(12):877-81

19. Morgental RD, Zanata LRN, Rahde NM. Evaluation of artificial lateral and secondary canals filling with different obturation techniques. Rev Odonto Cienc 2008; 23:273-7.

20. Tanomaru-Filho M, Sant'Anna A, Jr., Berbert FL, Bosso R, Guerreiro-Tanomaru JM. Ability of gutta-percha and Resilon to fill simulated lateral canals by using the Obtura II system. J Endod 2012; 38(5):676-9.

21. Venturi M. An ex vivo evaluation of a gutta-percha filling technique when used with two endodontic sealers: analysis of the filling of main and lateral canals. J Endod 2008; $34(9): 1105-10$
22. Goldberg F, Artaza LP, De Silvio A. Effectiveness of different obturation techniques in the filling of simulated lateral canals. J Endod 2001; 27(5):362-4.

23. Michelotto AL, Moura-Netto C, Araki AT, Akisue E, Sydney GB. Penetration of a resin-based filling material into lateral root canals and quality of obturation by different techniques. Braz Oral Res 2015; 29(1):1-5.

24. Marciano MA, Bramante CM, Duarte MA, Delgado RJ, Ordinola-Zapata R, Garcia RB. Evaluation of single root canals filled using the lateral compaction, Tagger's hybrid, Microseal and Guttaflow techniques. Braz Dent J 2010; 21(5):411-5.

25. Wu D, Tang Z, Zhang G, Liu W. The sealing ability of a new silicone-based root canal filling material (GuttaFlow): an in vitro study using the percentage of gutta-percha-filled area. Dent Mater J 2011; 30(5):569-75.

26. Schäfer E, Schrenker C, Zupanc J, Bürklein S. Percentage of gutta-percha filled areas in canals obturated with cross-linked gutta-percha core-carrier systems, single-cone and lateral compaction technique. J Endod 2016;(2):294-8.

Endereço para correspondência:

Renata Dornelles Morgental

Rua Marechal Floriano Peixoto, 1184

97015-372, Santa Maria, RS, Brasil

Telefones: (55) 3220-9272, (55) 99978-6669

E-mail: remorgental@hotmail.com

Recebido: 10/05/2017. Aceito: 01/07/2017. 